\title{
Dealuminated Beta Zeolite Modified by Alkaline Earth Metals
}

\author{
Karolina Chalupka $\mathbb{D}^{1}{ }^{1}$ Renata Sadek, ${ }^{1,2}$ Laetitia Valentin, ${ }^{2}$ Yannick Millot, ${ }^{2}$ \\ Christophe Calers, ${ }^{2}$ Magdalena Nowosielska, ${ }^{1}$ Jacek Rynkowski, ${ }^{1}$ and Stanislaw Dzwigaj $\mathbb{D D}^{2}$ \\ ${ }^{1}$ Lodz University of Technology, Institute of General and Ecological Chemistry, Zeromskiego 116, 90-924 Lodz, Poland \\ ${ }^{2}$ Sorbonne Universités, UPMC Univ Paris 06, CNRS, UMR 7197, Laboratoire de Réactivité de Surface, 4 Place Jussieu, Case 178, \\ F-75252 Paris, France
}

Correspondence should be addressed to Karolina Chalupka; karolina.chalupka@p.lodz.pl and Stanislaw Dzwigaj; stanislaw.dzwigaj@upmc.fr

Received 27 April 2018; Accepted 1 November 2018; Published 2 December 2018

Academic Editor: Hossein Kazemian

Copyright (c) 2018 Karolina Chalupka et al. This is an open access article distributed under the Creative Commons Attribution License, which permits unrestricted use, distribution, and reproduction in any medium, provided the original work is properly cited.

\begin{abstract}
Alkaline Earth metals (Mg, Sr, and Ca) were incorporated into the dealuminated mesoporous beta zeolite (DeAlBeta) by the twostep postsynthesis method. Physicochemical properties of both unmodified and alkaline Earth metal-modified DeAlBeta zeolite were characterized by XRD, DR UV-vis, FTIR, TPD of $\mathrm{NH}_{3}$ and $\mathrm{CO}_{2}, \mathrm{NMR}$, and XPS. The dealumination of beta zeolite led to decrease of its acidity and basicity. The incorporation of alkaline Earth metals into the framework of dealuminated beta zeolite did not affect its structure. The modification of DeAlBeta with a small amount of alkaline Earth metals increases the number of acidic centers, which may be related to the formation of framework $\mathrm{Mg}$ (Ca or Sr) (II) Lewis acidic sites.
\end{abstract}

\section{Introduction}

The world of science puts special emphasis on the development of new stable materials with the interesting acid-base properties. Due to the unique features (e.g., high specific surface area and strictly defined size of pores) of zeolite, they are among the most promising materials. Moreover, the introduction of various metals into their structures may beneficially change their properties [1-5].

Due to the presence of Lewis and Brønsted acidic sites in these materials, they have been used as catalysts in many reactions [6, 7]. Moreover, an introduction of an alkali [8-10] and/or alkaline Earth metal [11-13] into the zeolite structure can lead to modification of their basic properties.

The incorporation of alkali metal cations increases the basicity of oxygen atoms, which are present in the framework of the zeolite [14]. The most common methods used for the preparation of such zeolite systems are ion exchange [15] and impregnation [13].

Obtained in this way alkali metal-loaded zeolite catalysts have been applied in several reactions such as methylation of toluene [13] and phenol oxidation [16]. As it has been shown, the acid-base properties of alkaline Earth metalscontaining zeolites significantly affect the yields of these processes. This is why focusing more attention on a better control of acid-base properties of zeolite catalysts is required. It may allow obtaining more efficient catalysts for different processes, e.g., conversion of ethanol to propylene [17], syngas to dimethyl ether [12], or methanol to olefin [18].

In this work, we have used a two-step postsynthesis method, developed earlier by Dzwigaj et al. [19-23] to obtain $\mathrm{Mg}-$, Sr-, and Ca-containing DeAlBeta zeolite with isolated, mononuclear $\mathrm{Sr}(\mathrm{II}), \mathrm{Ca}(\mathrm{II})$, and $\mathrm{Mg}(\mathrm{II})$ species. As obtained $\mathrm{Mg}-$, Sr-, and Ca-containing DeAlBeta zeolite catalysts were characterized by XRD, BET, FTIR, XRD, DR UV-vis, $\mathrm{NH}_{3}$ TPD, $\mathrm{CO}_{2}$-TPD, NMR, and XPS.

\section{Materials and Methods}

Tetraethylammonium beta (TEABeta) zeolite provided by RIPP (China) was divided into two fractions. The first one was calcined (air, $15 \mathrm{~h}, 550^{\circ} \mathrm{C}$ ) in order to obtain an organicfree HAlBeta zeolite $(\mathrm{Si} / \mathrm{Al}=18)$. The second fraction of TEABeta was treated in a $13 \mathrm{~mol} \cdot \mathrm{L}^{-1} \mathrm{HNO}_{3}$ aqueous 
solution $\left(4 \mathrm{~h}, 80^{\circ} \mathrm{C}\right)$ to obtain a partially dealuminated DeAlBeta support $(\mathrm{Si} / \mathrm{Al}=64)$ with vacant $\mathrm{T}$-atom sites (where $\mathrm{T}=\mathrm{Al}$ ). DeAlBeta was then separated by centrifugation, washed with distilled water, and dried overnight at $80^{\circ} \mathrm{C}$. To incorporate $\mathrm{Sr}^{2+}, \mathrm{Ca}^{2+}$, or $\mathrm{Mg}^{2+}$ ions in vacant T-atom sites, $2 \mathrm{~g}$ of DeAlBeta was stirred under aerobic conditions for $24 \mathrm{~h}$ at $25^{\circ} \mathrm{C}$ in $200 \mathrm{~mL}$ aqueous solution of $\mathrm{Sr}$ $\left(\mathrm{NO}_{3}\right)_{2} \cdot 4 \mathrm{H}_{2} \mathrm{O}(\mathrm{pH}=2.0), \mathrm{Mg}\left(\mathrm{NO}_{3}\right)_{2} \cdot 6 \mathrm{H}_{2} \mathrm{O}(\mathrm{pH}=2.1)$, or $\mathrm{Ca}\left(\mathrm{NO}_{3}\right)_{2} \cdot 4 \mathrm{H}_{2} \mathrm{O}(\mathrm{pH}=2.0)$. Then, the suspensions were stirred for $2 \mathrm{~h}$ at $80^{\circ} \mathrm{C}$ until water was evaporated, and the resulting solids were dried in air at $80^{\circ} \mathrm{C}$ for $24 \mathrm{~h}$. Then, the solids were calcined in air at $500^{\circ} \mathrm{C}$ for $3 \mathrm{~h}$ and labelled $\mathrm{Mg}_{2.0}$ DeAlBeta (2.0 wt.\% Mg), $\mathrm{Sr}_{2.0}$ DeAlBeta (2.1 wt.\% Sr), and $\mathrm{Ca}_{2.0}$ DeAlBeta $(2.2$ wt.\% Ca) - in parentheses the real content of metals determined by XRF.

The elemental composition of tested samples was performed by the X-ray fluorescence (XRF) (SPECTRO XEPOS, AMETEK Materials Analysis Division) at room temperature.

Textural characterization of the samples was determined by nitrogen adsorption at $-195^{\circ} \mathrm{C}$ on Micrometrics ASAP 2020 analyzer. Prior to the analysis, ca. $0.08 \mathrm{~g}$ of the sample was degassed for $2 \mathrm{~h}$ at $350^{\circ} \mathrm{C}$. The total surface area was determined using the Brunauer-Emmeet-Teller (BET) method. The micropore volumes and the micropore surface area were obtained by the t-plot method. The BarrettJoyner-Halenda $(\mathrm{BJH})$ model applied to the adsorption branch of the isotherm was used to obtain the mesopore size distribution.

The powder X-ray diffraction patterns (XRD) experiments were performed on a PANalytical Empyrean diffractometer equipped with the $\mathrm{Cu} \mathrm{Ka}$ radiation $(\lambda=$ $154.05 \mathrm{pm})$ in the $2 \theta$ range of $5^{\circ}-90^{\circ}$.

The Fourier-transform infrared (FT-IR) spectra of the studied zeolites samples were recorded on a Nicolet iS10 Thermo Scientific equipped with the deuterated triglycine sulfate (DTGS) detector with a resolution of $4 \mathrm{~cm}^{-1}$, at room temperature and ambient atmosphere in the range of $4000-400 \mathrm{~cm}^{-1}$. Before measurements, samples were mixed with potassium bromide at mass ratio $1: 100$ (zeolite: $\mathrm{KBr}$ ) and then pressed at 1.5-2 tons $\mathrm{cm}^{-2}$ for 2 minutes.

In a case of pyridine adsorption, the FT-IR spectrometer Bruker Vector 22 equipped with the DTGS detector with a resolution of $2.0 \mathrm{~cm}^{-1}$ and number of scans 128 was used. Samples were pressed at $\sim 0.2$ tons $\mathrm{cm}^{-2}$ into thin wafers of ca. $10 \mathrm{mg} \cdot \mathrm{cm}^{-2}$ and placed inside the IR cell. After calcination at $450^{\circ} \mathrm{C}$ for $3 \mathrm{~h}$ in $\mathrm{O}_{2}$ (100 Torr) followed by outgassing at $300^{\circ} \mathrm{C}\left(10^{-3} \mathrm{~Pa}\right)$ for $1 \mathrm{~h}$, the wafers were contacted at room temperature with gaseous pyridine (1 Torr) via a separate cell containing liquid pyridine. After saturation with pyridine, the samples were outgassed at $150^{\circ} \mathrm{C}\left(10^{-3} \mathrm{~Pa}\right)$. FT-IR spectra were recorded at room temperature in the range of $4000-400 \mathrm{~cm}^{-1}$.

The temperature-programmed desorption of ammonia $\left(\mathrm{NH}_{3}-\mathrm{TPD}\right)$ measurements were carried out in a quartz reactor using gaseous ammonium. $\mathrm{NH}_{3}$ was adsorbed on zeolite catalysts (c.a. $0.100 \mathrm{~g}$ ) at $100^{\circ} \mathrm{C}$ for 10 minutes in flowing He. Before $\mathrm{NH}_{3}$ adsorption, catalysts were dried at $500^{\circ} \mathrm{C}$ in $\mathrm{He}$ flow for 30 minutes (total gas flow: $\left.40 \mathrm{~cm}^{3} \cdot \mathrm{min}^{-1}\right)$. The temperature-programmed desorption of
$\mathrm{NH}_{3}$ was carried out in the temperature range $25-500^{\circ} \mathrm{C}$, after removing physisorbed ammonium from the catalyst with helium flow at $100^{\circ} \mathrm{C}$ for 10 minutes.

The temperature-programmed desorption of $\mathrm{CO}_{2}\left(\mathrm{CO}_{2}{ }^{-}\right.$ TPD) measurements were carried out in a quartz reactor using gaseous carbon dioxide. $\mathrm{CO}_{2}$ was adsorbed on zeolite catalysts (c.a. $0.100 \mathrm{~g}$ ) at $40^{\circ} \mathrm{C}$ for 30 minutes in flowing He. Before $\mathrm{CO}_{2}$ adsorption, catalysts were dried at $500^{\circ} \mathrm{C}$ in $\mathrm{He}$ flow for 30 minutes (total gas flow: $40 \mathrm{~cm}^{3} \cdot \mathrm{min}^{-1}$ ). The temperature-programmed desorption of $\mathrm{CO}_{2}$ was carried out in the temperature range $25-500^{\circ} \mathrm{C}$, after removing physisorbed ammonia from the catalyst.

The diffuse reflectance UV-Vis (DR UV-Vis) spectra were recorded under ambient atmosphere on a Cary 5000 Varian spectrometer equipped with a double integrator with polytetrafluoroethylene as a reference.

The X-ray photoelectron spectroscopy (XPS) analyses were performed using an Omicron Argus X-ray photoelectron spectrometer with a monochromated AlK $\alpha$ radiation source $(\mathrm{h} v=1486.6 \mathrm{eV})$ having a $280 \mathrm{~W}$ electron beam power. The emission of photoelectrons from the sample was analyzed under ultrahigh vacuum conditions ( $\leq 10-10$ Torr). Spectra were carried out with $100 \mathrm{eV}$ pass energy for the survey scan and $20 \mathrm{eV}$ pass energy for the other regions. Binding energies were calibrated against the $\mathrm{C} 1$ s binding energy at $284.7 \mathrm{eV}$. The spectra were fitted using Casa XPS v.2.3.16 software (Casa Software Ldt, UK) and applying a Gaussian/Lorentzian ratio G/L equal to 70/30.

${ }^{27} \mathrm{Al}$ MAS NMR spectra were recorded at $130.33 \mathrm{MHz}$ with 1.3 Ps excitation pulse (S/6), $0.5 \mathrm{~s}$ for the recycle delay, and 1024 accumulations. The spectra were acquired at a spinning rate of $12 \mathrm{kHz}$ in a $4 \mathrm{~mm}$ zirconia rotor.

${ }^{29} \mathrm{Si}$ MAS NMR spectra were recorded at $99.36 \mathrm{MHz}$ with a Bruker Avance 500 spectrometer and $7 \mathrm{~mm}$ (external diameter) zirconia rotors, with $\mathrm{CP}\left({ }^{1} \mathrm{H}_{-}{ }^{29} \mathrm{Si} \mathrm{CP}-\mathrm{MAS} \mathrm{NMR}\right)$ and without $\left({ }^{29} \mathrm{Si}\right.$ MAS NMR). Chemical shifts of silicon were measured by reference to tetramethylsilane (TMS). ${ }^{29} \mathrm{Si}$ MAS NMR spectra were obtained with a $7 \mathrm{~mm}$ zirconia rotor at $6 \mathrm{kHz}$ spinning speed, $4 \mu \mathrm{s}$ excitation pulse duration, and $10 \mathrm{~s}$ recycle delay. Polydimethylsilane (PDMS) was used for setting the Hartmann-Hahn condition. The proton $\pi / 2$ pulse duration, the contact time, and recycle delay were $3.4 \mu \mathrm{s}, 5 \mathrm{~ms}$, and $5 \mathrm{~s}$, respectively.

${ }^{1} \mathrm{H}$ MAS NMR spectra were recorded with a Bruker Avance 500 spectrometer and $4 \mathrm{~mm}$ zirconia rotors with a $90^{\circ}$ pulse duration of $3 \mu \mathrm{s}$ and a recycle delay of $5 \mathrm{~s}$. The MAS equipment for rotation $(12 \mathrm{kHz})$ was carefully cleaned with ethanol to avoid spurious proton signals. The probe signal was subtracted from the total free induction decay.

\section{Results and Discussion}

3.1. Textural and Structure Characterization (BET, XRD, and FTIR). $\mathrm{N}_{2}$ adsorption-desorption isotherms employed to estimate the textural properties of all samples under study are shown in Figure 1, and the data are listed in Table 1. Exemplary, Figure 2 presents the detailed plots, used for calculations, for the DeAlBeta sample. Neither dealumination nor the introducing of alkaline Earth metal 


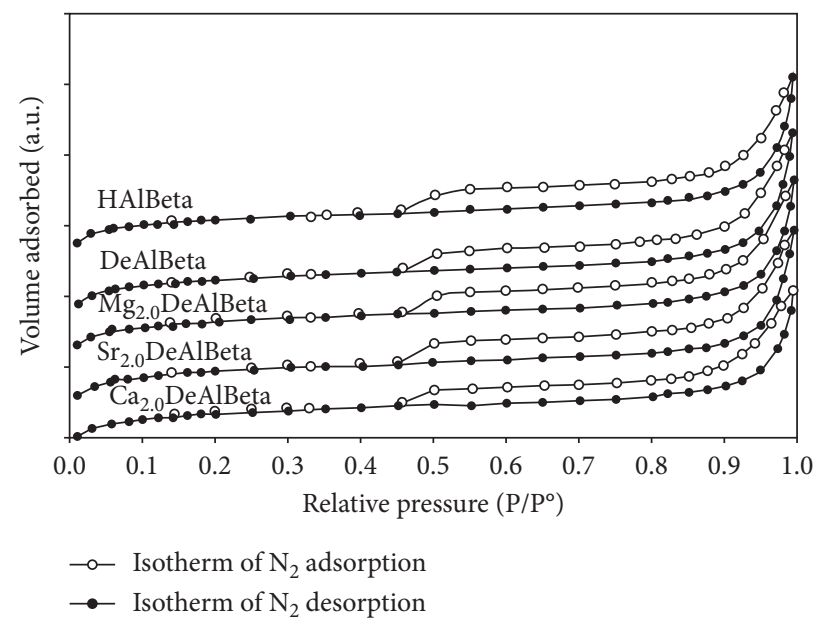

Figure 1: $\mathrm{N}_{2}$ adsorption-desorption isotherms of HAlBeta, DeAlBeta, $\mathrm{Mg}_{2.0}$ DeAlBeta, $\mathrm{Sr}_{2.0}$ DeAlBeta, and $\mathrm{Ca}_{2.0}$ DeAlBeta samples.

TABLE 1: Surface characteristic of samples determined by the $\mathrm{N}_{2}$ adsorption-desorption method.

\begin{tabular}{lcccccc}
\hline Sample & $\begin{array}{c}\text { Total specific surface } \\
\text { area, TSSA }\left(\mathrm{m}^{2} \cdot \mathrm{g}^{-1}\right)\end{array}$ & $\begin{array}{c}\text { Micropore } \\
\text { area }\left(\mathrm{m}^{2} \cdot \mathrm{g}^{-1}\right)\end{array}$ & $\begin{array}{c}\text { External surface } \\
\text { area }\left(\mathrm{m}^{2} \cdot \mathrm{g}^{-1}\right)\end{array}$ & $\begin{array}{c}\text { Total pore } \\
\text { volume }\left(\mathrm{cm}^{3} \cdot \mathrm{g}^{-1}\right)\end{array}$ & $\begin{array}{c}\text { Micropore } \\
\text { volume }\left(\mathrm{cm}^{3} \cdot \mathrm{g}^{-1}\right)\end{array}$ & $\begin{array}{c}\text { Average pore } \\
\mathrm{diameter}(\mathrm{nm})\end{array}$ \\
\hline HAlBeta & 474 & 414 & 60.0 & 0.317 & 0.216 & 4.70 \\
DeAlBeta & 498 & 435 & 63.0 & 0.331 & 0.223 & 4.68 \\
$\mathrm{Mg}_{2.0}$ DeAlBeta & 468 & 407 & 61.0 & 0.312 & 0.212 & 4.62 \\
$\mathrm{Sr}_{2.0}$ DeAlBeta & 498 & 436 & 62.0 & 0.328 & 0.227 & 4.48 \\
$\mathrm{Ca}_{2.0}$ DeAlBeta & 472 & 411 & 61.0 & 0.308 & 0.214 \\
\hline
\end{tabular}

changes the textural parameters of the samples significantly. All of them show the typical type I isotherm with a substantial $\mathrm{H} 4$ hysteresis loop from $\mathrm{P} / \mathrm{P} 0=0.45$ with a characteristic step-down in the desorption branch associated with the hysteresis loop closure [24]. Such course of isotherms indicates a micromeso hierarchical porous textural feature. The relatively high micropore volume (ca. 0.22 $\mathrm{cm}^{3} \mathrm{~g}^{-1}$ indicates the crystalline character of the zeolite framework [25]. The $\mathrm{BJH}$ average pore diameter (4.40$4.70 \mathrm{~nm}$ ) indicates the creation of intracrystalline mesopores. The differences of parameters given in Table 1 between individual samples are not meaningful and do not exceed $7 \%$. However, the dealumination of the zeolite leads to the slight decrease in the total specific surface area and increase in total pore volume. The subsequent introducing of alkaline Earth metal results in an opposite effect, the most pronounced for $\mathrm{Mg}_{2.0}$ DeAlBeta, which may be connected with the deep incorporation of the small $\mathrm{Mg}^{2+}$ ions into the zeolite structure.

Figure 3 presents the XRD patterns of HAlBeta, DeAlBeta, and $\mathrm{Mg}_{-}, \mathrm{Sr}-$, and $\mathrm{Ca}$-containing DeAlBeta samples, in which two main diffraction peaks at $2 \theta$ around $7.7^{\circ}[101]$ and $22.4^{\circ}[302]$ are observed, characteristic for beta materials, in agreement with earlier reports [26-29]. Thus, one can conclude that the presence of the alkaline Earth metal does not affect the structure of DeAlBeta zeolite. A position of the main diffraction peak of the dealuminated DeAlBeta sample $\left(22.30^{\circ}\right)$ is slightly shifted comparing to that of HAlBeta one $\left(22.39^{\circ}\right)$. For the samples modified with alkaline Earth metals, it shows the intermediate values, i.e., $22.34^{\circ}, 22.35^{\circ}$, and $22.37^{\circ}$, for $\mathrm{Sr}_{2.0}$ DeAlBeta, $\mathrm{Mg}_{2.0}$ DeAlBeta, and $\mathrm{Ca}_{2.0}$ DeAlBeta, respectively.

Although the observed changes are very tiny, they may indicate the slight matrix contraction under dealumination of HAlBeta and the expansion under introduction of metals ions into the DeAlBeta structure. The peaks which could be ascribed to alkaline Earth metal species for all tested samples are not observed, what is probably related with good dispersion of the alkaline Earth metals in the zeolite as a result of their reaction with silanol groups of vacant T-atom sites and/or ion exchange with a proton of HAlBeta. The lack of alkaline Earth metal diffraction peaks may also suggest that $\mathrm{Mg}, \mathrm{Ca}$, or $\mathrm{Sr}$ species have entered the zeolite structure.

The FT-IR spectra in the range of $\mathrm{T}-\mathrm{O}(\mathrm{T}=\mathrm{Si}$ or $\mathrm{Al})$ of HAlBeta, DeAlBeta, $\mathrm{Mg}_{2.0}$ DeAlBeta, $\mathrm{Sr}_{2.0}$ DeAlBeta, and $\mathrm{Ca}_{2.0}$ DeAlBeta are presented in Figure 4(a). The bands attributed to asymmetric and symmetric external O-T-O stretching vibration (at 790-793 and $1227-1231 \mathrm{~cm}^{-1}$ ), asymmetric internal $\mathrm{O}-\mathrm{T}-\mathrm{O}$ stretching vibration (at 1077$1084 \mathrm{~cm}^{-1}$ ), and structural vibration (at 521-526, 571-575, and $621-623 \mathrm{~cm}^{-1}$ ) are very similar for all samples under study. It confirms that the incorporation of alkaline Earth metal ions into the DeAlBeta zeolite does not affect its structure $[3,30,31]$.

The bands at $947 \mathrm{~cm}^{-1}$ on HAlBeta and $955 \mathrm{~cm}^{-1}$ on DeAlBeta spectra may be attributed to the stretching vibrations of $\mathrm{Si}-\mathrm{O}$ belonging to uncoupled $\mathrm{SiO} 4$ tetrahedra, in line with previous works on silica and various siliceous zeolites [21,32-34]. The band around $950 \mathrm{~cm}^{-1}$ disappears for $\mathrm{Mg}_{2.0}$ DeAlBeta and is less intensive for $\mathrm{Ca}_{2.0}$ DeAlBeta 


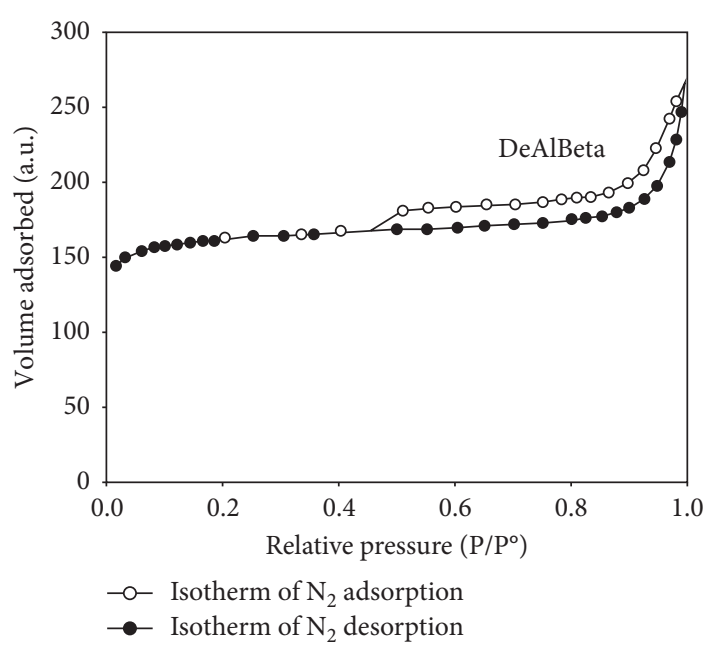

(a)

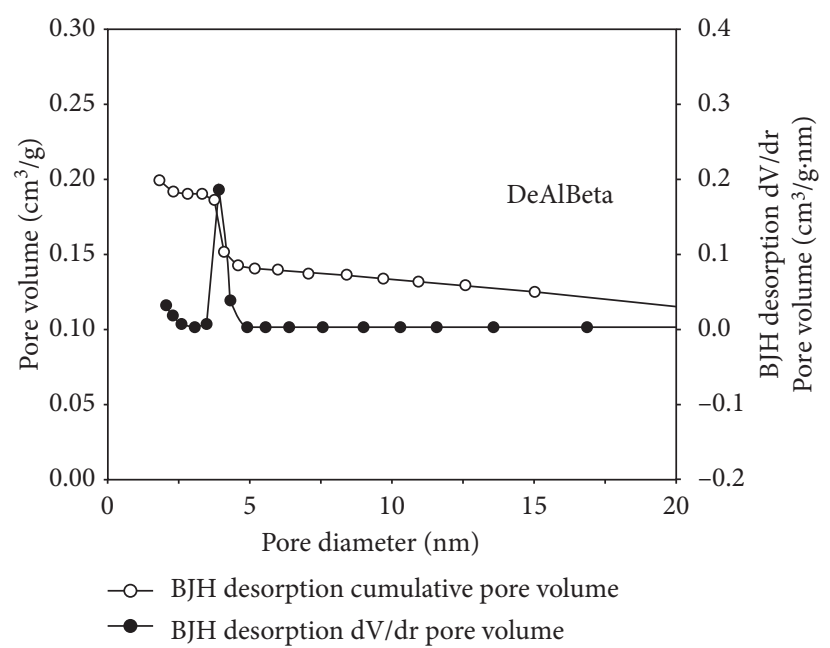

(b)

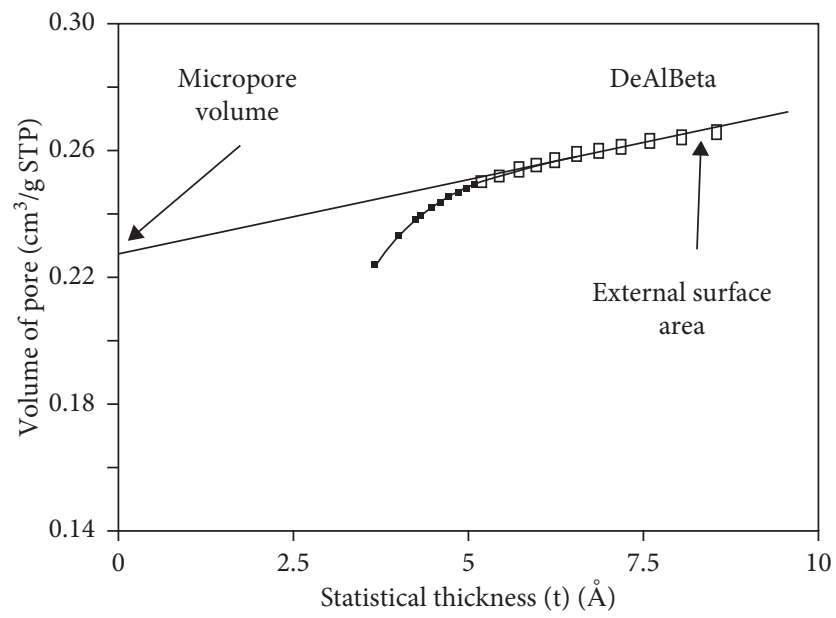

(c)

FIgure 2: The plots for the DeAlBeta sample: (a) $\mathrm{N}_{2}$ adsorption-desorption isotherm; (b) BJH pore size distribution; (c) t-plot.

and $\mathrm{Sr}_{2.0}$ DeAlBeta. This phenomenon suggests the reaction of alkaline Earth metals with silanol groups.

The difference in the intensity of the discussed band may be related to the differentiated ionic radius of magnesium (86 pm), calcium (114 pm), and strontium (132 pm). The smaller the ionic radius of the alkaline Earth metals, the stronger its incorporation into the vacant $\mathrm{T}$-atom sites, and therefore, the higher the consumption of silanol groups. The FT-IR spectra in the range of $\mathrm{O}-\mathrm{H}$ stretching vibrations are shown in Figure 4(b). If we compare the spectra of HAlBeta with DeAlBeta, one can observe a disappearance of the bands at 3684 and $3743 \mathrm{~cm}^{-1}$ related to the presence of isolated $\mathrm{Al}-\mathrm{OH}$ and external $\mathrm{Si}-\mathrm{OH}$ groups in HAlBeta and an appearance of the bands at 3737,3714 , and $3519 \mathrm{~cm}^{-1}$ attributed to the isolated internal, terminal, and hydrogenbonded $\mathrm{SiOH}$ groups, respectively $[27,35,36]$. It suggests that, upon treatment of HAlBEA zeolite with the $13 \mathrm{~mol} \cdot \mathrm{L}^{-1}$ $\mathrm{HNO}_{3}$ aqueous solution, aluminum is removed and vacant $\mathrm{T}$-atom sites associated with silanol groups are formed, in line with our previous work on microporous beta zeolite.
The introduction of alkaline Earth metals into the DeAlBeta zeolite decreases the intensity of the bands at 3743, 3714 , and $3519 \mathrm{~cm}^{-1}$, suggesting that the alkaline Earth metals ions react with silanol groups of vacant $\mathrm{T}$-atom sites. This effect is the most pronounced for the $\mathrm{Mg}_{2.0}$ DeAlBeta sample.

3.2. Acid and Basic Sites Characterization (Py-IR, $\mathrm{NH}_{3}-\mathrm{TPD}$, and $\mathrm{CO}_{2}$-TPD). To get the information about the Brønsted and Lewis acid sites, FTIR of pyridine adsorption was carried out. The spectra are presented in Figure 5. For HAlBeta, the bands at 1548 and $1637 \mathrm{~cm}^{-1}$ correspond to pyridinium ions chemisorbed on Brønsted acidic sites, those at 1455, and $1622 \mathrm{~cm}^{-1}$ to pyridine interacting with strong Lewis acidic centers and that at $1492 \mathrm{~cm}^{-1}$ to pyridine interacting with both Brønsted and Lewis acid sites. The intensity of the appropriate bands on the spectrum of DeAlBeta is significantly lower, and the band at $1455 \mathrm{~cm}^{-1}$ completely disappears. Thus, the dealumination of beta zeolite leads to the 


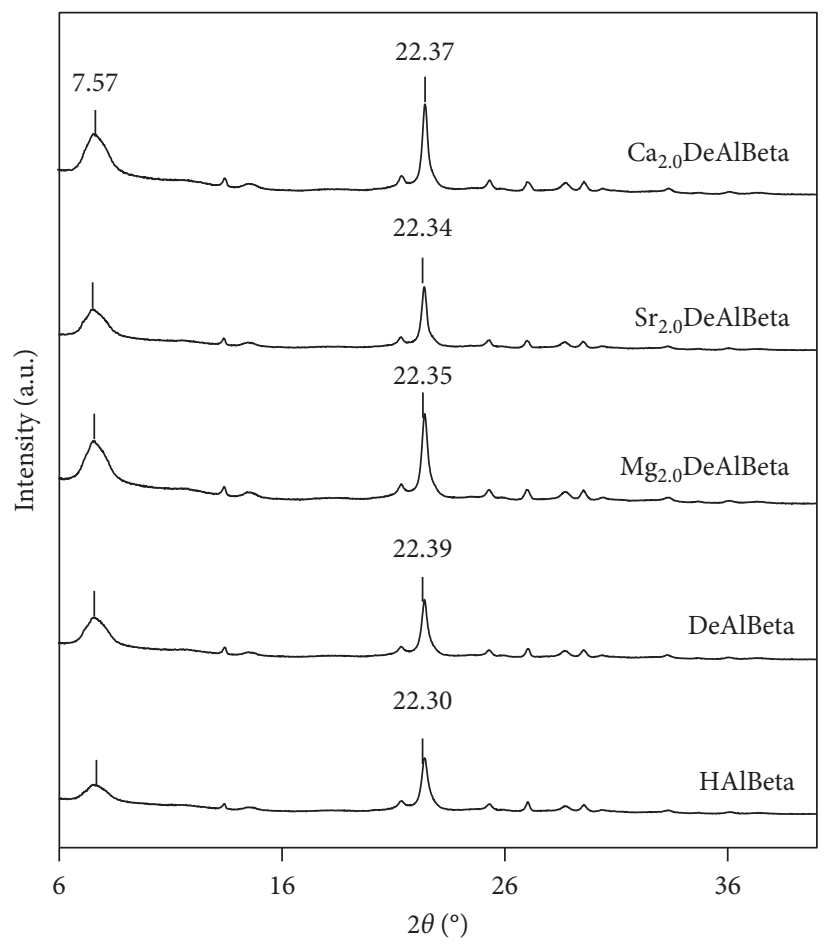

Figure 3: XRD patterns of HAlBeta, DeAlBeta, $\mathrm{Mg}_{2.0}$ DeAlBeta, $\mathrm{Sr}_{2.0}$ DeAlBeta, and $\mathrm{Ca}_{2.0}$ DeAlBeta samples.

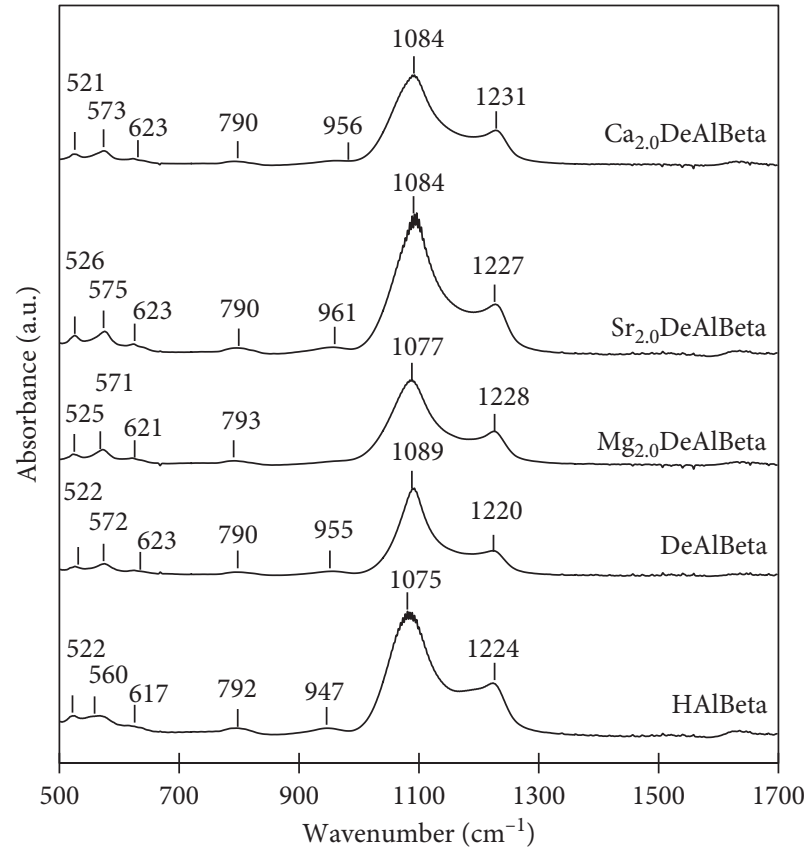

(a)

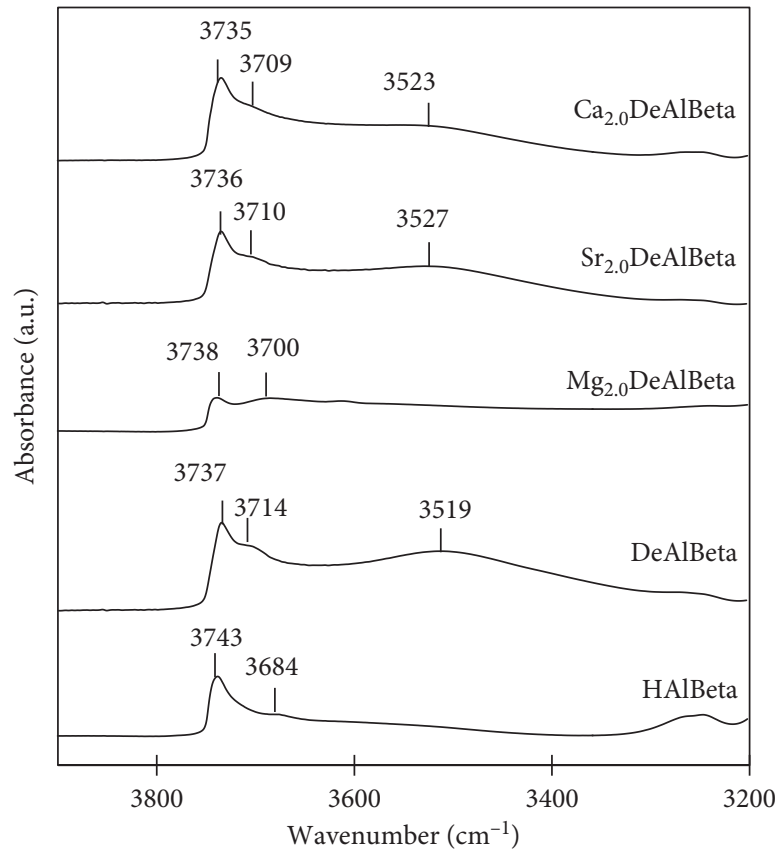

(b)

Figure 4: FTIR spectra of HAlBeta, DeAlBeta, $\mathrm{Mg}_{2.0}$ DeAlBeta, $\mathrm{Sr}_{2.0}$ DeAlBeta, and $\mathrm{Ca}_{2.0}$ DeAlBeta samples in the (a) framework vibration region and (b) vibrational range of $\mathrm{OH}$ groups.

decrease of both Lewis and Brønsted acidic sites in beta zeolite $[27,37]$.

The incorporation of alkaline Earth metals into DeAlBeta zeolite results in the appearance of the band at $1445-1448 \mathrm{~cm}^{-1}$. This band may be attributed to Lewis sites, the population of which increases with decreasing alkaline Earth cation radius [38]. Indeed, the highest intensity of a band at $1448 \mathrm{~cm}^{-1}$ for $\mathrm{Mg}_{2.0}$ DeAlBeta is connected with the enhanced incorporation of magnesium ions into the framework of DeAlBeta as well-dispersed $\mathrm{Mg}$ (II) Lewis sites. 


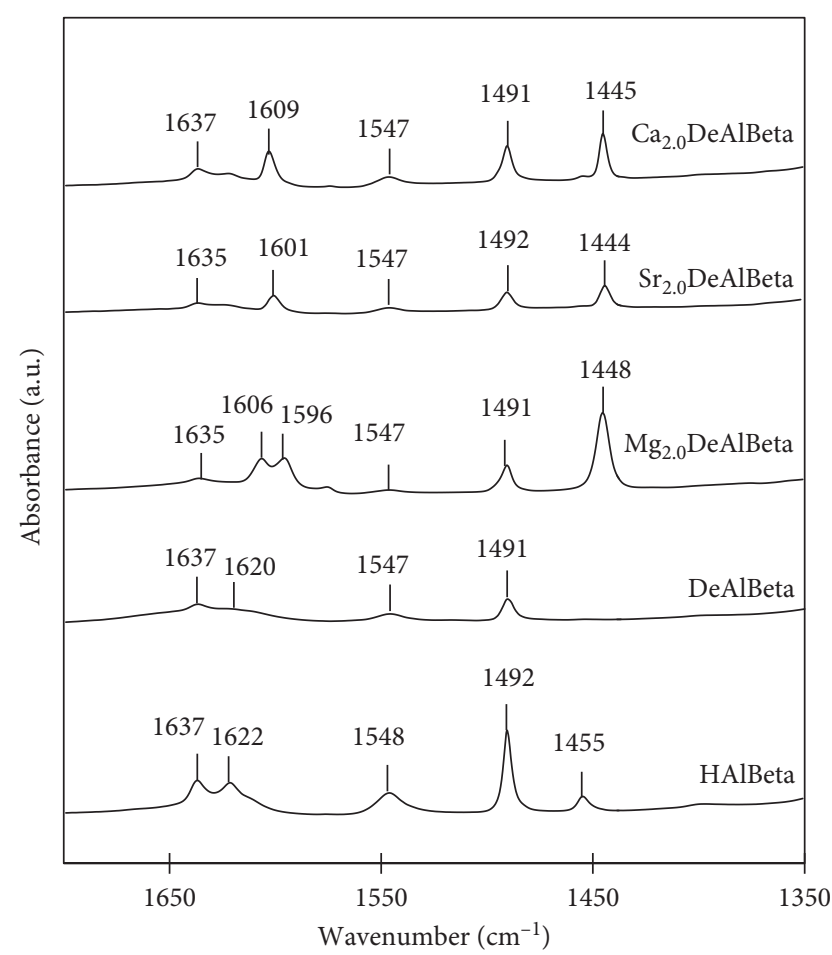

FIgUre 5: FTIR spectra of HAlBeta, DeAlBeta, $\mathrm{Mg}_{2.0}$ DeAlBeta, $\mathrm{Sr}_{2.0}$ DeAlBeta, and $\mathrm{Ca}_{2.0}$ DeAlBeta samples recorded at room temperature after adsorption at room temperature and desorption of pyridine at $300^{\circ} \mathrm{C}$.

Moreover, for alkaline Earth metal-modified zeolite, the bands around of 1596-1609 $\mathrm{cm}^{-1}$ are observed, which can be ascribed to pyridine interacting with another type of weaker Lewis acidic centers [27, 37].

$\mathrm{NH}_{3}$-TPD was carried out to monitor the acid strength and the amounts of acid sites on the samples under study. The results are presented in Figure 6(a). The profile of the initial HAlBeta sample shows the typical course with two unresolved peaks with maxima at around 250 and $414-429^{\circ} \mathrm{C}$ corresponding to ammonia desorbed from the weak and strong acid sites, respectively [39]. Roughly, the low temperature peak may be described to the Lewis, whereas the high temperature one to the Brønsted acidic sites [37, 40]. For the remaining samples (DeAlBeta, $\mathrm{Mg}_{2.0}$ DeAlBeta, $\mathrm{Sr}_{2.0}$ DeAlBeta, and $\mathrm{Ca}_{2.0}$ DeAlBeta), the intensity of both peaks diminishes, and the maximum of the low temperature peak is shifted about $30^{\circ} \mathrm{C}$ towards lower temperatures what suggests that these zeolites possesses lower strength of Lewis acidic sites. Moreover, for alkaline Earth metal-modified zeolites, one can observe lower intensity of the high temperature peak, especially expressed for $\mathrm{Mg}_{2.0}$ DeAlBeta. This observation confirms again an incorporation of $\mathrm{Mg}^{2+}$ ions into the zeolite framework connected with the decrease of the amount of strong Brønsted sites.

The quantitative analysis of $\mathrm{NH}_{3}$-TPD measurements is shown in Table 2. One can note that dealumination of beta zeolite leads to decreasing of its acidity as a result of removal of the $\mathrm{Al}$ from zeolite, in agreement with the earlier report [40]. However, the introduction of a small amount of alkaline Earth metals (c.a. 2 wt.\%) into DeAlBeta increases the number of acidic centers. It may be related to an incorporation of these metals into the framework of this material and/or ion exchange with the proton of DeAlBeta zeolite with formation of Lewis acidic sites.

Results of $\mathrm{CO}_{2}$-TPD for all tested samples are presented in Figure 6(b) and Table 2. The profile of HAlBeta depicts one peak with maximum at $250^{\circ} \mathrm{C}$, which can be assigned to medium basic sites. The dealumination of beta zeolite leads to the decrease in its basicity what reflects both the shift of the desorption peak's maximum to about $215^{\circ} \mathrm{C}$ and the significant decrease in the amount of adsorbed $\mathrm{CO}_{2}$. The introduction of alkaline Earth metals into the zeolite changes its basicity ambiguously. For $\mathrm{Sr}_{2.0}$ DeAlBeta and $\mathrm{Ca}_{2.0}$ DeAlBeta, the course of $\mathrm{CO}_{2}$-TPD is similar to that of DeAlBeta, although the maxima of desorption peaks are slightly shifted towards higher temperature and the amount of adsorbed $\mathrm{CO}_{2}$ decreases. The most pronounced shift of the maximum to the temperature $300^{\circ} \mathrm{C}$ is observed for $\mathrm{Mg}_{2.0}$ DeAlBeta. Results seem to confirm that the basicity of alkaline Earth metal-modified zeolites depends on both structural type and chemical composition [11, 14].

3.3. Spectroscopic Characterization (DRUV-Vis, XPS, ${ }^{27} \mathrm{Al},{ }^{1} \mathrm{H}$, and ${ }^{29}$ Si MAS NMR). The DR UV-vis spectra of DeAlBeta, $\mathrm{Mg}_{2.0}$ DeAlBeta, $\mathrm{Sr}_{2.0}$ DeAlBeta, and $\mathrm{Ca}_{2.0}$ DeAlBeta are shown in Figure 7. For $\mathrm{Mg}_{2.0}$ DeAlBeta, $\mathrm{Sr}_{2.0}$ DeAlBeta, and $\mathrm{Ca}_{2.0}$ DeAlBeta, the broad band are seen at 267, 279, and $263 \mathrm{~nm}$, respectively, related to isolated mononuclear $\mathrm{Mg}$ (II), $\mathrm{Sr}(\mathrm{II})$, and $\mathrm{Ca}(\mathrm{II})$ species well dispersed in the beta structure. The band at around of $267-279 \mathrm{~nm}$ could be attributed to pseudotetrahedral $\mathrm{Mg}(\mathrm{II}), \mathrm{Sr}(\mathrm{II})$, and $\mathrm{Ca}(\mathrm{II})$ species formed as a results of reaction of magnesium, strontium, and calcium ions with silanol groups of vacant T-atom sites of mesoporous DeAlBeta zeolite, in line with earlier reports on Sr-SAPO-34 [41] and MgAPSO-34 [42]. In the case of the $\mathrm{Mg}_{2.0}$ DeAlBeta sample, the very small and broad band at about $300 \mathrm{~nm}$ is seen. It is probably related to present of tetrahedral $\mathrm{Mg}$ species with 4- and/or 3-coordination in the zeolite framework [4].

To confirm the oxidation state of the prepared samples, XPS analysis was performed, and the results of which are shown in Figure 8. The $\mathrm{O}$ 1s spectra (not shown here) of all studied samples depict one single peak at binding energy c.a. $533.0 \mathrm{eV}$ that can be attributed to the $\mathrm{Si}-\mathrm{O}-\mathrm{Si}$ bond [43]. The $\mathrm{Mg}$ 2s spectrum of $\mathrm{Mg}_{2.0}$ DeAlBeta (Figure 8(a)) presents one broad peak at binding energy $90.1 \mathrm{eV}$, which can be attributed to $\mathrm{Mg}^{2+}$. A similar peak for MgZSM-5 was reported by Cai et al. [44]. The $\mathrm{Ca} 2 \mathrm{p}$ spectrum of $\mathrm{Ca}_{2.0}$ DeAlBeta (Figure 8(b)) shows a doublet structure and two peaks with maxima at binding energy $351.7 \mathrm{eV}$ and $348.2 \mathrm{eV}$ corresponding to $\mathrm{Ca} 2 \mathrm{p}_{1 / 2}$ and $\mathrm{Ca} 2 \mathrm{p}_{3 / 2}$, respectively, and indicates the presence of $\mathrm{Ca}^{2+}$ species in a different environment [45]. The $\mathrm{Sr} 3 \mathrm{~d}$ spectrum of $\mathrm{Sr}_{2.0}$ DeAlBeta is presented in Figure $8(\mathrm{c})$. The location of the $\mathrm{Sr} 3 \mathrm{~d}_{5 / 2}$ spectrum at $136.3 \mathrm{eV}$ and that of $\mathrm{Sr} 3 \mathrm{~d}_{3 / 2}$ at $134.5 \mathrm{eV}$ proves the existence of $\mathrm{Sr}^{2+}$ [46].

${ }^{27} \mathrm{Al}$ MAS NMR spectroscopy is an efficient probe to determine the coordination and local structure of specific 


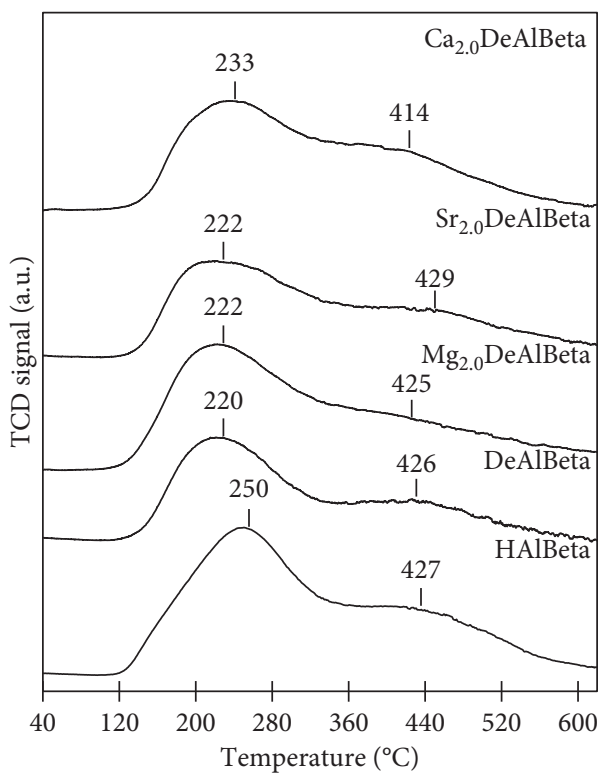

(a)

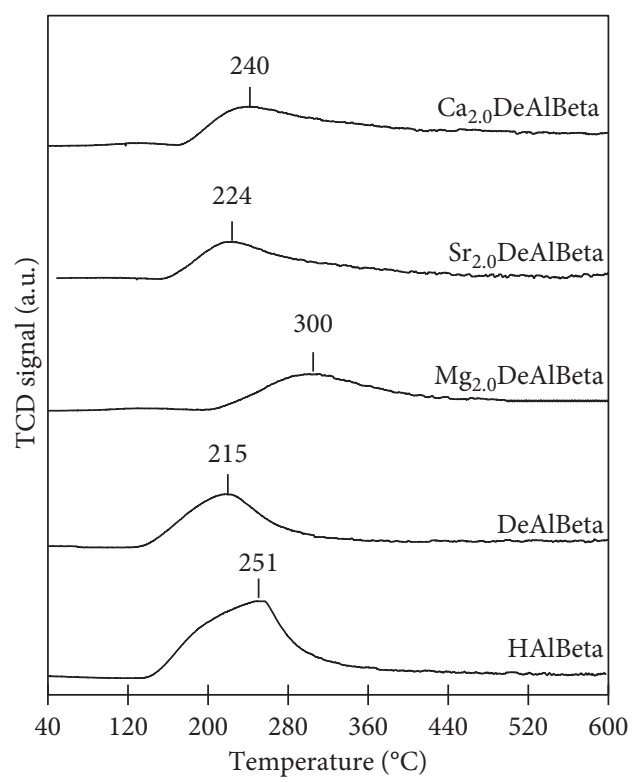

(b)

FiguRE 6: Temperature-programmed desorption profiles of ammonia (a) and carbon dioxide (b) for HAlBeta, DeAlBeta, $\mathrm{Mg}_{2.0} \mathrm{DeAlBeta}$, $\mathrm{Sr}_{2.0}$ DeAlBeta, and $\mathrm{Ca}_{2.0}$ DeAlBeta samples.

TABLE 2: Surface quantitative analysis of TPD-NH $\mathrm{NH}_{3}$ and TPD- $\mathrm{CO}_{2}$ measurements on HAlBeta, DeAlBeta, $\mathrm{Sr}_{2.0}$ DeAlBeta, $\mathrm{Ca}_{2.0}$ DeAlBeta, and $\mathrm{Mg}_{2.0}$ DeAlBeta.

\begin{tabular}{lcc}
\hline Sample & $\begin{array}{c}\text { Amount of } \mathrm{NH}_{3} \\
\text { adsorbed }\left(\mu \mathrm{mol} \cdot \mathrm{g}^{-1}\right)\end{array}$ & $\begin{array}{c}\text { Amount of } \mathrm{CO}_{2} \\
\text { adsorbed }\left(\mu \mathrm{mol} \cdot \mathrm{g}^{-1}\right)\end{array}$ \\
\hline HAlBeta & 1830 & 2391 \\
DeAlBeta & 1181 & 1761 \\
$\mathrm{Mg}_{2.0}$ DeAlBeta & 1408 & 1457 \\
$\mathrm{Sr}_{2.0}$ DeAlBeta & 1335 & 1564 \\
$\mathrm{Ca}_{2.0}$ DeAlBeta & 1345 & 1550 \\
\hline
\end{tabular}

aluminum species in zeolite materials [47-49]. Both tetrahedral and octahedral Al species can be easily distinguished basing on their different chemical shifts. A position of $\mathrm{Al}$ resonance gives a good indication of the local environment of the aluminum site. For example, framework aluminum atoms in tetrahedral coordination $\left(\mathrm{Al}_{\mathrm{Td}}\right)$ exhibit a signal at 50-60 ppm, while extraframework aluminum atoms in octahedral coordination $\left(\mathrm{Al}_{\mathrm{Oh}}\right)$ usually give a signal at $\sim 0 \mathrm{ppm}$.

Figure 9 shows the ${ }^{27} \mathrm{Al}$ MAS NMR spectra of HAlBeta $(\mathrm{Si} / \mathrm{Al}=18)$ and DeAlBeta $(\mathrm{Si} / \mathrm{Al}=64)$ samples. The spectra of both samples are similar. Two inseparable signals at about 54.5 and 56.9 ppm suggest the presence of two kinds of $\mathrm{Al}_{\mathrm{Td}}$ sites in both HAlBeta and DeAlBeta samples [27]. The decrease of the absolute signal intensity for DeAlBeta comparing to HAlBeta indicates the higher amount of aluminum species in the HAlBeta sample and confirms removal of $\mathrm{Al}$ from $\mathrm{HAlBeta}$ upon treatment with acid nitric [27].

On the ${ }^{1} \mathrm{H}$ MAS NMR spectrum of HAlBeta (Figure $10(\mathrm{a})$ ), one main broad peak is observed at $4.85 \mathrm{ppm}$ due to protons of $\mathrm{H}$-bonded silanol groups present at vacant T-atom sites of HAlBeta zeolite, in line with earlier data on

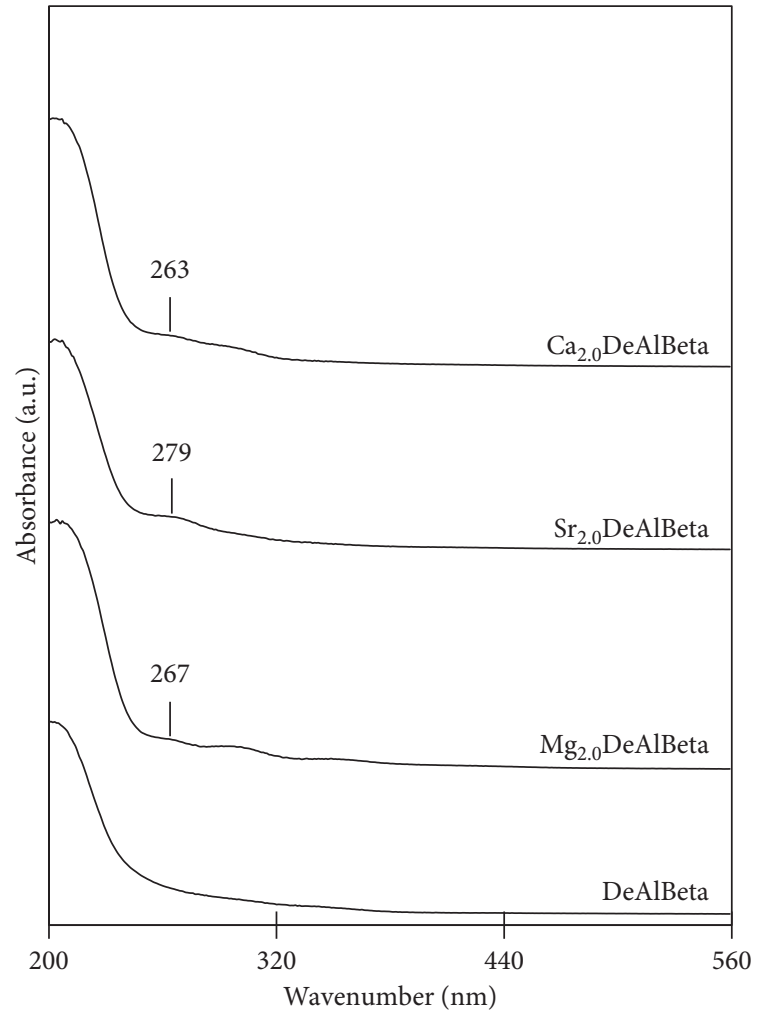

FIGURE 7: DR UV-vis spectra recorded at room temperature and ambient atmosphere for DeAlBeta, $\mathrm{Mg}_{2.0}$ DeAlBeta, $\mathrm{Sr}_{2.0}$ DeAlBeta, and $\mathrm{Ca}_{2.0}$ DeAlBeta samples.

zeolites [50-53]. For DeAlBeta, three main peaks are observed at $1.14-1.25,3.64-3.74$, and $5.45 \mathrm{ppm}$ due to protons of isolated and/or terminal $\mathrm{SiO}-\mathrm{H}$ and $\mathrm{H}$-bonded silanol 


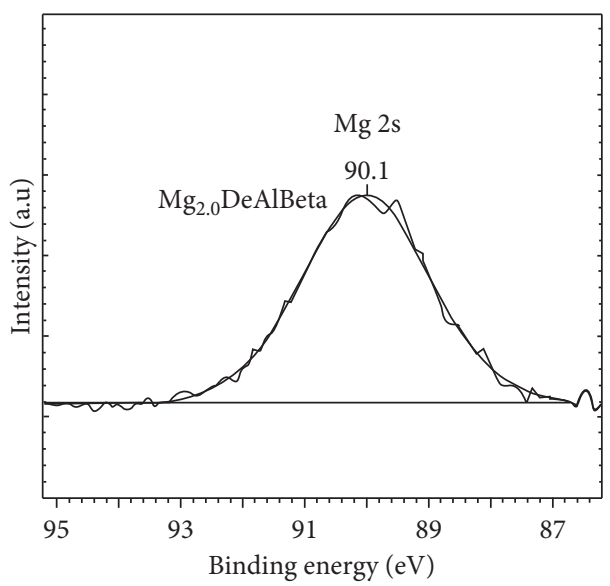

(a)

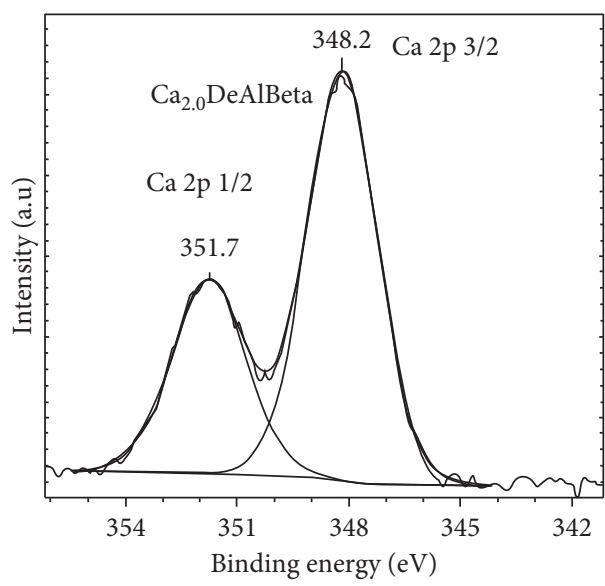

(b)

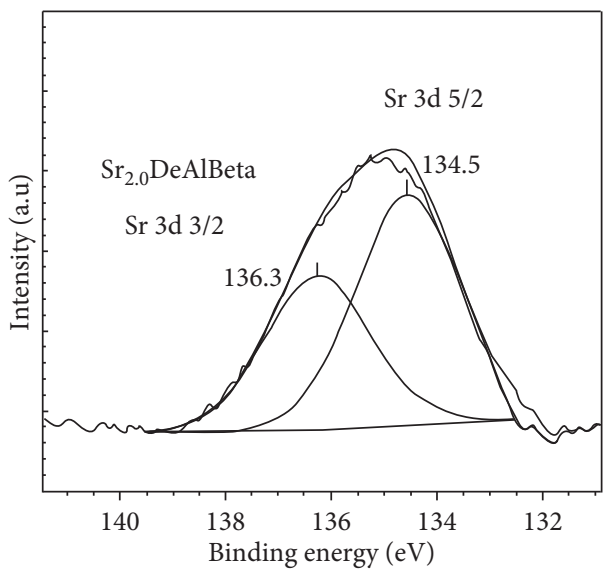

(c)

Figure 8: X-ray photoelectron spectra recorded at room temperature for (a) Mg 2s of $\mathrm{Mg}_{2.0}$ DeAlBeta, (b) Ca 2p of Ca ${ }_{2.0} \mathrm{DeAlBeta}$, and (c) Sr 3d of $\mathrm{Sr}_{2.0}$ DeAlBeta.

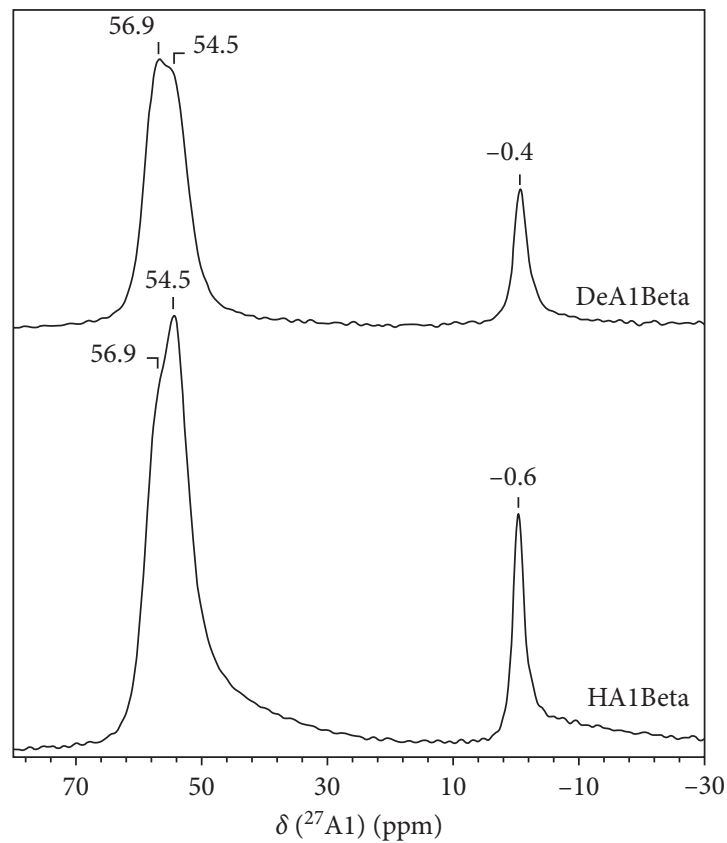

FIGURE 9: ${ }^{27} \mathrm{Al}$ MAS NMR spectra recorded at room temperature in a $4 \mathrm{~mm}$ (the external diameter) zirconia rotor of as-prepared HAlBeta and DeAlBeta. groups present at vacant $\mathrm{T}$-atom sites, respectively. The peak at $3.6-3.7 \mathrm{ppm}$ is probably due to protons of $\mathrm{H}$-bonded $\mathrm{SiOH}$ groups located in a second kind of crystallographic sites. This shift is comparable with that observed at $3.20 \mathrm{ppm}$ for $\mathrm{H}$-bonded $\mathrm{SiO}-\mathrm{H}$ groups in silicalite and silica $[54,55]$. The disappearance of the peak at 5.45 and at 3.6-3.7 ppm upon incorporation of $\mathrm{Mg}, \mathrm{Sr}$, and $\mathrm{Ca}$ ions in DeAlBeta evidences the reaction of $\mathrm{Mg}, \mathrm{Sr}$, and $\mathrm{Ca}$ nitrate precursor with both $\mathrm{H}$-bonded $\mathrm{SiO}-\mathrm{H}$ groups. The ${ }^{1} \mathrm{H}$ MAS NMR spectra of $\mathrm{Mg}_{2.0}$ DeAlBeta, $\mathrm{Sr}_{2.0}$ DeAlBeta, and $\mathrm{Ca}_{2.0} \mathrm{DeAl}$ Beta exhibit the main peak at around $1.23-1.27 \mathrm{ppm}$ due to the protons of isolated $\mathrm{SiO}-\mathrm{H}$ groups with smaller intensity than that present in DeAlBeta zeolite. It confirms that $\mathrm{Mg}$, $\mathrm{Sr}$, and $\mathrm{Ca}$ ions introduced in DeAlBeta react not only with hydrogen bonded $\mathrm{SiO}-\mathrm{H}$ but also with isolated $\mathrm{SiO}-\mathrm{H}$ groups.

The ${ }^{29} \mathrm{Si}$ MAS NMR spectrum of DeAlBeta (Figure 10(b)) shows three resonances at $-103.7,111.2$, and $-114.8 \mathrm{ppm}$. The peaks at -111.2 and $-114.8 \mathrm{ppm}$ are due to framework $\mathrm{Si}$ atoms in the $\mathrm{Si}(\mathrm{OSi})_{4}$ environment, located at different crystallographic sites, in line with the earlier report [56]. The peak at $-103.7 \mathrm{ppm}$ is assigned to $\mathrm{Si}$ atoms in the $\mathrm{Si}$ $(\mathrm{OH})(\mathrm{OSi})_{3}$ environment as revealed by a strong increase of intensity of the peak at $-103.7 \mathrm{ppm}$ when ${ }^{1} \mathrm{H}_{-}{ }^{29} \mathrm{Si} \mathrm{CP}-\mathrm{MAS}$ 


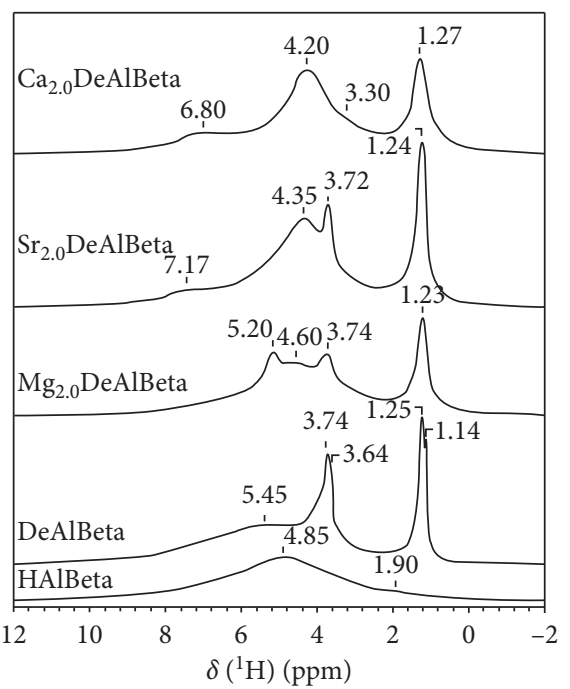

(a)

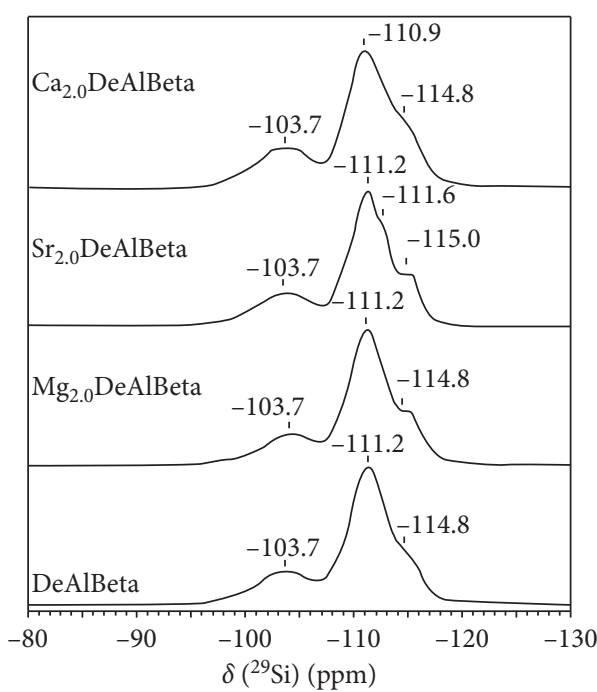

(b)

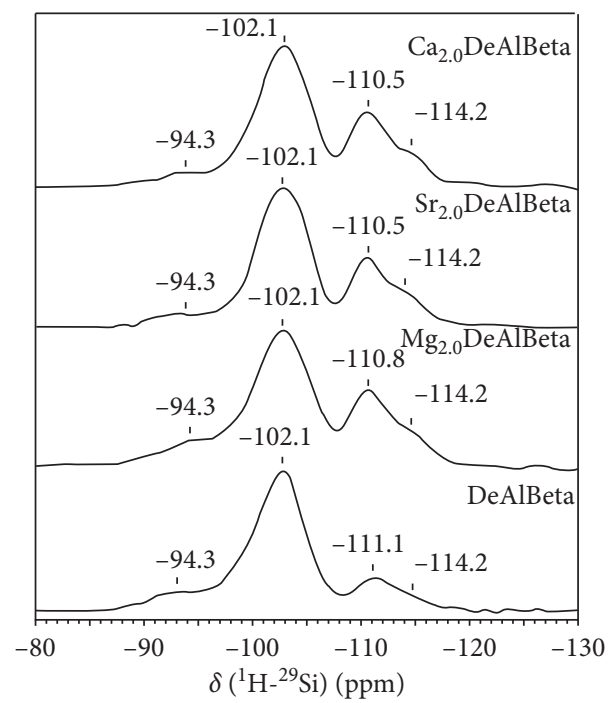

(c)

Figure 10: ${ }^{1} \mathrm{H}$ MAS NMR (a), ${ }^{29} \mathrm{Si}$ MAS NMR (b), and ${ }^{1} \mathrm{H}_{-}{ }^{29} \mathrm{Si} \mathrm{CP}$ MAS NMR (c) spectra recorded at room temperature in $4 \mathrm{~mm}$ (the external diameter) zirconia rotor of as-prepared HAlBeta and partially dealuminated DeAlBeta.

NMR is applied (Figure 10(c)), the technique which preferentially enhances the signal of the ${ }^{29} \mathrm{Si}$ nuclei close to protons as it is in the case of the $\mathrm{Si}(\mathrm{OH})(\mathrm{OSi})_{3}$ site.

After incorporation of $\mathrm{Mg}, \mathrm{Sr}$, and $\mathrm{Ca}$ ions into the DeAlBeta, the relative intensity of the peak at around $-102.1 \mathrm{ppm}$ (compared to the intensity of the peak at around $-110 \mathrm{ppm}$ ) in ${ }^{1} \mathrm{H}^{-29} \mathrm{Si} \mathrm{CP}$-MAS NMR spectra is significantly reduced for $\mathrm{Mg}_{2.0}$ DeAlBeta, $\mathrm{Sr}_{2.0}$ DeAlBeta, and $\mathrm{Ca}_{2.0}$ DeAlBeta (Figure 10(c)), confirming the reaction between $\mathrm{Mg}, \mathrm{Sr}$, and $\mathrm{Ca}$ nitrate precursor and silanol groups of vacant $\mathrm{T}$-atom sites. However, the relatively small decrease of the intensity of the peak at $-102.1 \mathrm{ppm}$ suggests that only part of $\mathrm{Mg}, \mathrm{Sr}$, and $\mathrm{Ca}$ ions is incorporated in the framework position of DeAlBeta zeolite.

The change of the $\mathrm{Si}(\mathrm{OSi})_{4}$ environment takes place upon incorporation of $\mathrm{Mg}, \mathrm{Sr}$, and $\mathrm{Ca}$ ions into the framework of DeAlBeta zeolite as deduced from the appearance of better distinguished ${ }^{29} \mathrm{Si}$ MAS NMR peaks at -110.5 and $-114.2 \mathrm{ppm}$ for $\mathrm{Mg}_{2.0}$ DeAlBeta, $\mathrm{Sr}_{2.0}$ DeAlBeta, and $\mathrm{Ca}_{2.0}$ DeAlBeta, respectively (Figure 10(c)). For DeAlBeta, only the shoulder is observed in the ${ }^{1} \mathrm{H}-{ }^{29} \mathrm{Si}$ MAS NMR spectrum at around -114.8 (Figure 10(b)). It suggests that the presence of $\mathrm{Mg}, \mathrm{Sr}$, and $\mathrm{Ca}$ in the framework of $\mathrm{Mg}_{2.0}$ DeAlBeta, $\mathrm{Sr}_{2.0}$ DeAlBeta, and $\mathrm{Ca}_{2.0}$ DeAlBeta involves some modification of the $\mathrm{Si}$ environment.

\section{Conclusions}

For all tested samples, the bands attribute to asymmetric and symmetric external O-T-O stretching vibration, and asymmetric internal O-T-O stretching vibration and structural vibration are observed, which indicate that the structure of beta zeolite was preserved upon introduction of alkaline Earth 
metals into its framework. This conclusion was confirmed also by low temperature $\mathrm{N}_{2}$ adsorption and XRD studies.

On the basis of data obtained from XRD, IR (KBr), IRpyridine, and NMR, one can suggest that alkaline Earth metal ions are incorporated into framework of beta zeolite.

Their incorporation into the framework of DeAlBeta increases its Lewis acidity and changes its basicity. The mesoporous $\mathrm{Mg}_{2.0}$ DeAlBeta zeolite is characterized by the most basic character.

\section{Data Availability}

All results described in our manuscript are presented in this submitted work. If it is necessary to disclose the received data for verification purposes, the authors will share their original files.

\section{Conflicts of Interest}

The authors declare that they have no conflicts of interest.

\section{Acknowledgments}

The authors acknowledge IMPC (Institut des Materiaux de Paris Centre, FR2482) and the C'Nano projects of the Region Ile-de-France, for Omicron XPS apparatus funding.

\section{References}

[1] G. Perot and M. Guisnet, "Advantages and disadvantages of zeolites as catalysts in organic chemistry," Journal of Molecular Catalysis, vol. 61, no. 2, pp. 173-196, 1990.

[2] M. Granda Valdés, A. I. Pérez-Cordoves, and M. E. DíazGarcía, "Zeolites and zeolite-based materials in analytical chemistry," Trends in Analytical Chemistry, vol. 25, no. 1, pp. 24-30, 2006.

[3] F. Tian, Y. Wu, Q. Shen, X. Li, Y. Chen, and C. Meng, "Effect of $\mathrm{Si} / \mathrm{Al}$ ratio on mesopore formation for zeolite beta via $\mathrm{NaOH}$ treatment and the catalytic performance in $\alpha$-pinene isomerization and benzoylation of naphthalene," Microporous and Mesoporous Materials, vol. 173, pp. 129-138, 2013.

[4] R. Baran, Y. Millot, T. Onfroy, J.-M. Krafft, and S. Dzwigaj, "Influence of the nitric acid treatment on $\mathrm{Al}$ removal, framework composition and acidity of BEA zeolite investigated by XRD, FTIR and NMR," Microporous and Mesoporous Materials, vol. 163, pp. 122-130, 2012.

[5] M. Niwa, N. Katada, and K. Okumura, Characterization and Design of Zeolite Catalysts, Chapter 1, Introduction to Zeolite Science and Catalysis, Springer, Tottori, Japan, 2010.

[6] T. Ennaert, J. Van Aelst, J. Dijkmans et al., "Potential and challenges of zeolite chemistry in the catalytic conversion of biomass," Chemical Society Reviews, vol. 45, no. 3, pp. 584611, 2016.

[7] E. A. Pidko, Chemical Reactivity of Cation-Exchanged Zeolites. Chapter 1, Introduction, Technische Universiteit Eindhoven, Eindhoven, Netherlands, 2008.

[8] K. S. Walton, M. B. Abney, and M. D. Le Van, " $\mathrm{CO}_{2}$ adsorption in $\mathrm{Y}$ and $\mathrm{X}$ zeolites modified by alkali metal cation exchange," Microporous and Mesoporous Materials, vol. 91, no. 1-3, pp. 78-84, 2006.

[9] M. Huang and S. Kaliaguine, "Reactions of methylbutynol on alkali-exchanged zeolits. A Lewis acid-base selectivity study," Catalysis Letters, vol. 18, no. 4, pp. 373-389, 1993.
[10] C. Laborde-Boutet, G. Joly, A. Nicolaos, M. Thomas, and P. Magnoux, "Selectivity of thiophene/toluene competitive adsorptions onto zeolites. Influence of the alkali metal cation in FAU(Y)," Industrial and Engineering Chemistry Research, vol. 45, no. 24, pp. 8111-8116, 2006.

[11] K. Arishtirova, P. Kovacheva, and A. Predoeva, "Activity and basicity of $\mathrm{BaO}$ modified zeolite and zeolite-type catalysts," Applied Catalysis A: General, vol. 243, no. 1, pp. 191-196, 2003.

[12] D. Mao, W. Yang, J. Xia, B. Zhang, Q. Song, and Q. Chen, "Highly effective hybrid catalyst for the direct synthesis of dimethyl ether from syngas with magnesium oxide-modified HZSM-5 as a dehydration component," Journal of Catalysis, vol. 230, no. 1, pp. 140-149, 2005.

[13] P. Kovacheva, K. Arishtirova, and S. Vassilev, "MgO/NaX zeolite as basic catalyst for oxidative methylation of toluene with methane," Applied Catalysis A: General, vol. 210, no. 1-2, pp. 391-395, 2001.

[14] D. Barthomeuf, "Framework induced basicity in zeolites," Microporous and Mesoporous Materials, vol. 66, no. 1, pp. 1-14, 2003.

[15] S. Chandrasekhar and P. N. Pramada, "Thermal studies of low silica zeolites and their magnesium exchanged forms," $\mathrm{Ce}$ ramics International, vol. 28, no. 2, pp. 177-175, 2002.

[16] T. Atoguchi and T. Kanougi, "Phenol oxidation over alkaline earth metal ion exchange beta zeolite in the presence of ketone," Journal of Molecular Catalysis A: Chemical, vol. 222, no. 1-2, pp. 253-257, 2004.

[17] D. Goto, Y. Harada, Y. Furumoto, A. Takahashi, T. Fujitani, and Y. Oumi, "Conversion of ethanol to propylene over HZSM-5 type zeolites containing alkaline earth metals," Applied Catalysis A: General, vol. 383, no. 1-2, pp. 89-95, 2010.

[18] S. Zhang, B. Zhang, Z. Gao, and Y. Han, "Methanol to olefin over Ca-modified HZSM-5 zeolites," Industrial and Engineering Chemistry Research, vol. 49, no. 5, pp. 2103-2106, 2010.

[19] S. Dzwigaj, M. J. Peltre, P. Massiani et al., "Incorporation of vanadium species in a dealuminated $\beta$ zeolite," Chemical Communications, vol. 1, pp. 87-88, 1998.

[20] S. Dzwigaj, M. Matsuoka, R. Franck, M. Anpo, and M. Che, "Probing different kinds of vanadium species in the VSi $\beta$ zeolite by Diffuse reflectance UV-Visible and photoluminescence spectroscopies," Journal of Physical Chemistry B, vol. 102, no. 33, pp. 6309-6312, 1998.

[21] S. Dzwigaj, P. Massiani, A. Davidson, and M. Che, "Role of silanol groups in the incorporation of $\mathrm{V}$ in $\beta$ zeolite," Journal of Molecular Catalysis A: Chemical, vol. 155, no. 1-2, pp. 169-182, 2000.

[22] S. Dzwigaj, "Recent advances in the incorporation and identification of vanadium species in microporous materials," Current Opinion in Solid State and Materials Science, vol. 7, no. 6, pp. 461-470, 2003.

[23] S. Dzwigaj, E. Ivanova, R. Kefirov et al., "Remarkable effect of the preparation method on the state of vanadium in BEA zeolite: lattice and extra-lattice V species," Catalysis Today, vol. 142, no. 3-4, pp. 185-191, 2009.

[24] M. Thommes, "Physical adsorption characterization of nanoporous materials," Chemie Ingenieur Technik, vol. 82, no. 7, pp. 1059-1073, 2010.

[25] L. Liu, H. Wang, R. Wang et al., "Hydrothermal synthesis of single-crystalline mesoporous beta zeolite assisted by N-methyl-2-pyrrolidone," RSC Advances, vol. 4, no. 74, pp. 39297-39300, 2014.

[26] S. Dzwigaj and M. Che, "Incorporation of Co(II) in dealuminated BEA zeolite at lattice tetrahedral sites evidenced by XRD, FTIR, Diffuse reflectance UV-Vis, EPR, and TPR," 
J. Phys. CJournal of Physical Chemistry B, vol. 110, no. 25, pp. 12490-12493, 2006.

[27] R. Hajjar, Y. Millot, P. P. Man, M. Che, and S. Dzwigaj, “Two kinds of framework Al sites studied in BEA zeolite by X-ray diffraction, Fourier transform infrared spectroscopy, NMR techniques, and V probe," Journal of Physical Chemistry C, vol. 112, no. 51, pp. 20167-20175, 2008.

[28] S. Mintova, V. Valtchev, T. Onfroy, C. Marichal, H. Knözinger, and T. Bein, "Variation of the Si/Al ratio in nanosized zeolite Beta crystals," Microporous and Mesoporous Materials, vol. 90, no. 1-3, pp. 237-245, 2006.

[29] K. A. Chalupka, W. K. Jozwiak, J. Rynkowski, W. Maniukiewicz, S. Casale, and S. Dzwigaj, "Partial oxidation of methane on NixAlBEA and NixSiBEA zeolite catalysts: remarkable effect of preparation procedure and $\mathrm{Ni}$ content," Applied Catalysis B: Environmental, vol. 146, pp. 227-236, 2014.

[30] K. Shanjiao, G. Yanjun, D. Tao, Z. Ying, and Z. Yanying, "Preparation and characterization of zeolite beta with low $\mathrm{SiO}_{2} / \mathrm{Al}_{2} \mathrm{O}_{3}$ ratio," Petroleum Science, vol. 4, no. 1, pp. 70-74, 2007.

[31] H. Fu, H. P. Li, H. Zhao, and T. F. Cai, "Preparation and modification of NaY/beta composite zeolite and adsorption performance," Petroleum Chemistry, vol. 54, no. 3, pp. 239244, 2014.

[32] F. Tielens, M. Calatayud, S. Dzwigaj, and M. Che, "What do vanadium framework sites look like in redox model silicate zeolites?," Microporous and Mesoporous Materials, vol. 119, no. 1-3, pp. 137-143, 2009.

[33] M. Hino and T. Sato, "Infrared absorption spectra of silica gel$\mathrm{H}_{2}{ }^{16} \mathrm{O}, \mathrm{D}_{2}{ }^{16} \mathrm{O}$, and $\mathrm{H}_{2}{ }^{18} \mathrm{O}$ systems," Bulletin of the Chemical Society of Japan, vol. 44, no. 1, pp. 33-37, 1971.

[34] M. Ocana, V. Fornes, and C. J. Serna, "The variability of the infrared powder spectrum of amorphous SiO2," Journal of Non-Crystalline Solids, vol. 107, no. 2-3, pp. 187-192, 1989.

[35] C. Jia, P. Massiani, and D. Barthomeuf, "Characterization by infrared and nuclear magnetic resonance spectroscopies of calcined beta zeolite," Journal of the Chemical Society, Faraday Transactions, vol. 89, no. 19, pp. 3659-3665, 1993.

[36] A. Janin, M. Maache, J. C. Lavalley, J. F. Joly, F. Raatz, and N. Szydlowski, "Study of the silanol groups in dealuminated HY zeolites: nature of the extraframework debris," Zeolites, vol. 11, no. 4, pp. 391-396, 1991.

[37] P. Boroń, L. Chmielarz, J. Gurgul et al., "The influence of the preparation procedures on the catalytic activity of Fe-BEA zeolites in SCR of NO with ammonia and N2O decomposition," Catalysis Today, vol. 235, pp. 210-225, 2014.

[38] J. W. Ward, "The nature of active sites on zeolites: III. The alkali and alkaline earth ion-exchanged forms," Journal of Catalysis, vol. 10, no. 1, pp. 34-46, 1968.

[39] P. Boroń, L. Chmielarz, J. Gurgul et al., "BEA zeolite modified with iron as effective catalyst for $\mathrm{N}_{2} \mathrm{O}$ decomposition and selective reduction of $\mathrm{NO}$ with ammonia," Applied Catalysis B: Environmental, vol. 138-139, pp. 434-445, 2013.

[40] A. M. Camiloti, S. L. Jahn, N. D. Velasco, L. F. Moura, and D. Cardosoa, "Acidity of Beta zeolite determined by TPD of ammonia and ethylbenzene disproportionation," Applied Catalysis A: General, vol. 182, no. 1, pp. 107-113, 1999.

[41] L. Zhang, M. E. Rivera-Ramos, and A. J. Hernández-Maldonado, "Location and valence state of strontium cations on the framework of a carbon dioxide selective porous silicoaluminophosphate," Chemical Engineering Journal, vol. 209, pp. 356-361, 2012.

[42] D. Zhang, Y. Wei, L. Xu et al., "MgAPSO-34 molecular sieves with various $\mathrm{Mg}$ stoichiometries: synthesis, characterization and catalytic behavior in the direct transformation of chloromethane into light olefins," Microporous and Mesoporous Materials, vol. 116, no. 1-3, pp. 684-692, 2008.

[43] D. Esquivel, A. J. Cruz-Cabeza, C. Jimenez-Sanchidrian, and F. J. Romero-Salguero, "Local environment and acidity in alkaline and alkaline-earth exchanged $\beta$ zeolite: structural analysis and catalytic properties," Microporous and Mesoporous Materials, vol. 142, no. 2-3, pp. 672-679, 2011.

[44] G. Y. Cai, G. Q. Chen, Q. X. Wang et al., "Surface properties of phosphorus and magnesium modified ZSM-5 zeolites," Studies in Surface Science and Catalysis, vol. 4, pp. 319-327, 1985.

[45] X. Chang, G. Lu, Y. Guo, Y. Wang, and Y. Guo, "A high effective adsorbent of NOx: preparation, characterization and performance of Ca-beta zeolites," Microporous and Mesoporous Materials, vol. 165, pp. 113-120, 2013.

[46] S. Fuentes, P. Munoz, N. Barraza, E. Chávez-Ángel, and C. M. Sotomayor Torres, "Structural characterization of slightly $\mathrm{Fe}$-doped $\mathrm{SrTiO}_{3}$ grown via a sol-gel hydrothermal synthesis," Journal of Sol-Gel Science and Technology, vol. 75, no. 3, pp. 593-601, 2015.

[47] S. Moreno and G. Poncelet, "Dealumination of small- and large- port mordenites: a comparative study," Microporous Materials, vol. 12, no. 4-6, pp. 197-222, 1997.

[48] T. H. Chen, K. Houthoofd, and P. J. Grobet, "Toward the aluminum coordination in dealuminated mordenite and amorphous silica-alumina: a high resolution 27Al MAS and MQ MAS NMR study," Microporous and Mesoporous Materials, vol. 86, no. 1-3, pp. 31-37, 2005.

[49] R. Rachwalik, Z. Olejniczak, J. Jiao, J. Huang, M. Hunger, and B. Sulikowski, "Isomerization of $\alpha$-pinene over dealuminated ferrierite-type zeolites," Journal of Catalysis, vol. 252, no. 2, pp. 161-170, 2007.

[50] G. L. Woolery, L. B. Alemany, R. M. Dessau, and A. W. Chester, "Spectroscopic evidence for the presence of internal silanols in highly siliceous ZSM-5," Zeolites, vol. 6, no. 1, pp. 14-16, 1986.

[51] C. Paze, A. Zecchina, S. Spera et al., "Comparative IR and ${ }^{1} \mathrm{H}-$ MAS NMR study of adsorption of $\mathrm{CD}_{3} \mathrm{CN}$ on zeolite $\mathrm{H}-\beta$ : evidence of the presence of two families of bridged Brnsted sites," Physical Chemistry Chemical Physics, vol. 1, no. 10, pp. 2627-2629, 1999.

[52] L. W. Beck and J. F. Haw, "Multinuclear NMR studies reveal a complex acid function for zeolite beta," Journal of Physical Chemistry, vol. 99, no. 4, pp. 1076-1079, 1995.

[53] L. W. Beck, J. L. White, and J. F. Haw, " $1 \mathrm{H}\{27 \mathrm{Al}\}$ doubleresonance experiments in solids: an unexpected observation in the 1H MAS spectrum of zeolite HZSM-5," Journal of the American Chemical Society, vol. 116, no. 21, pp. 9657-9661, 1994.

[54] C. E. Bronnimann, R. C. Zeigler, and G. E. Maciel, "Proton NMR study of dehydration of the silica gel surface," Journal of the American Chemical Society, vol. 110, no. 7, pp. 2023-2026, 1988.

[55] G. E. Maciel and P. D. Ellis, "NMR characterization of silica and alumina surfaces," in NMR Techniques in Catalysis. Chemical Industries Series 55, A. T. Bell and A. Pines, Eds., pp. 231-309, Marcel Dekker, New York, NY, USA, 1994.

[56] C. A. Fyfe, H. Strobl, G. T. Kokotailo, C. T. Pasztor, G. E. Barlow, and S. Bradley, "Correlations between lattice structures of zeolites and their ${ }^{29} \mathrm{Si}$ MAS n.m.r. spectra: zeolites KZ-2, ZSM-12, andet Ba," Zeolites, vol. 8, no. 2, pp. 132-136, 1988. 

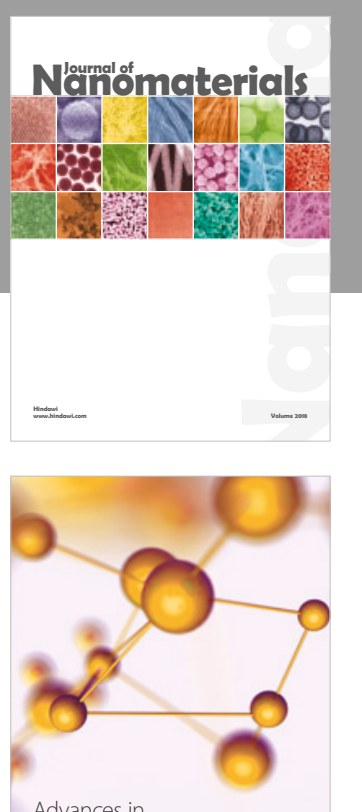

Physical Chemistry
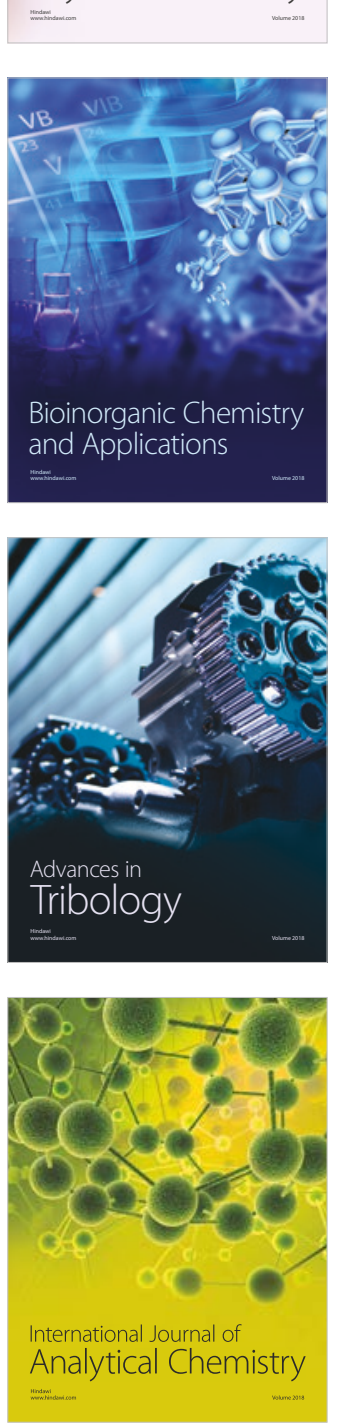

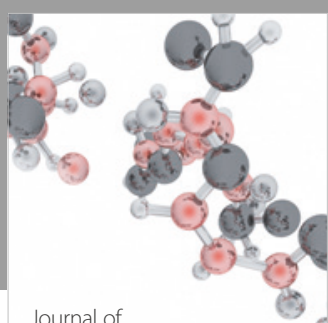

Analytical Methods

in Chemistry

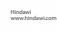

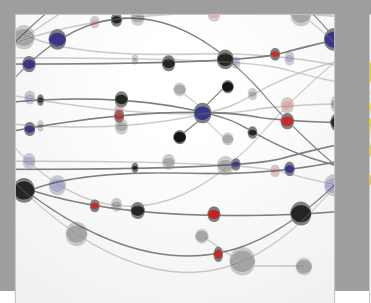

The Scientific World Journal

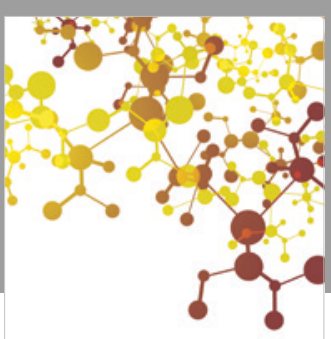

Journal of

Applied Chemistry
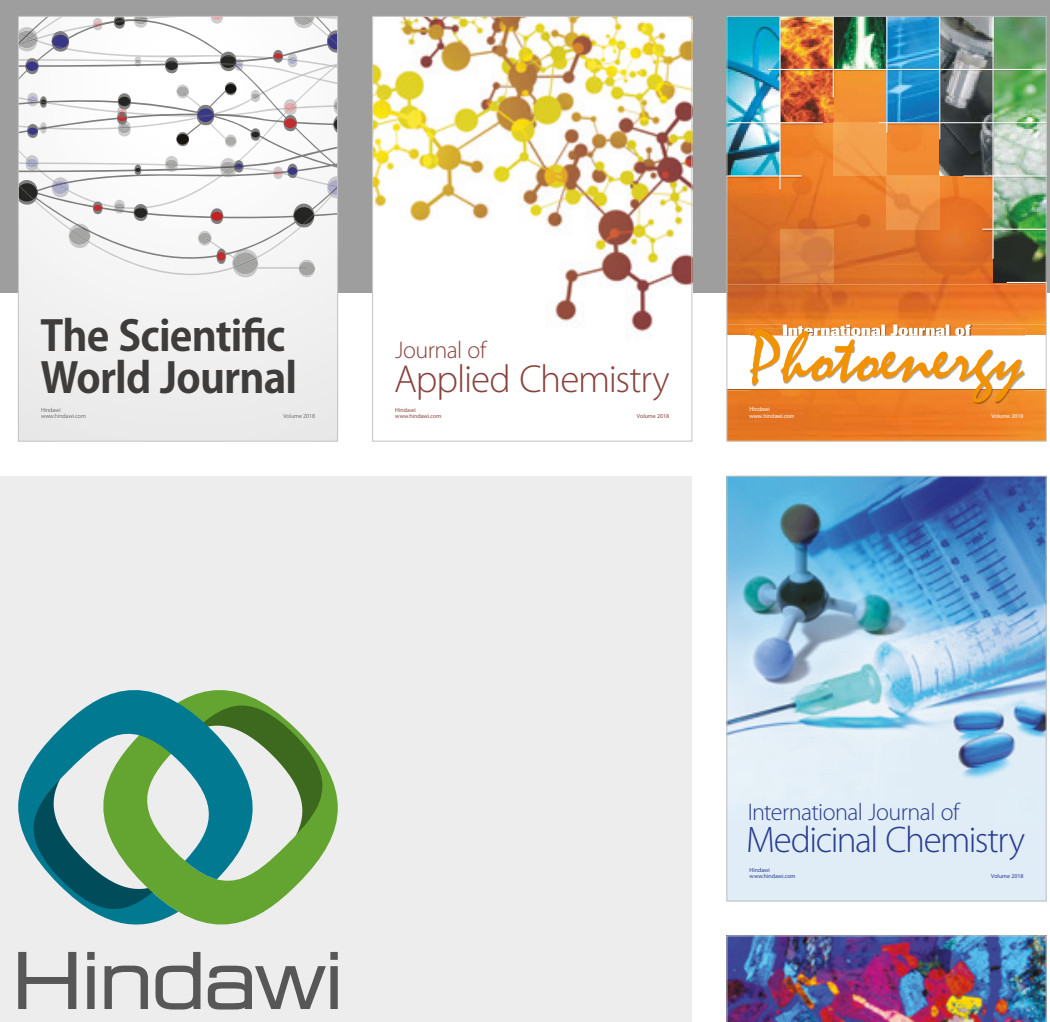

Submit your manuscripts at

www.hindawi.com
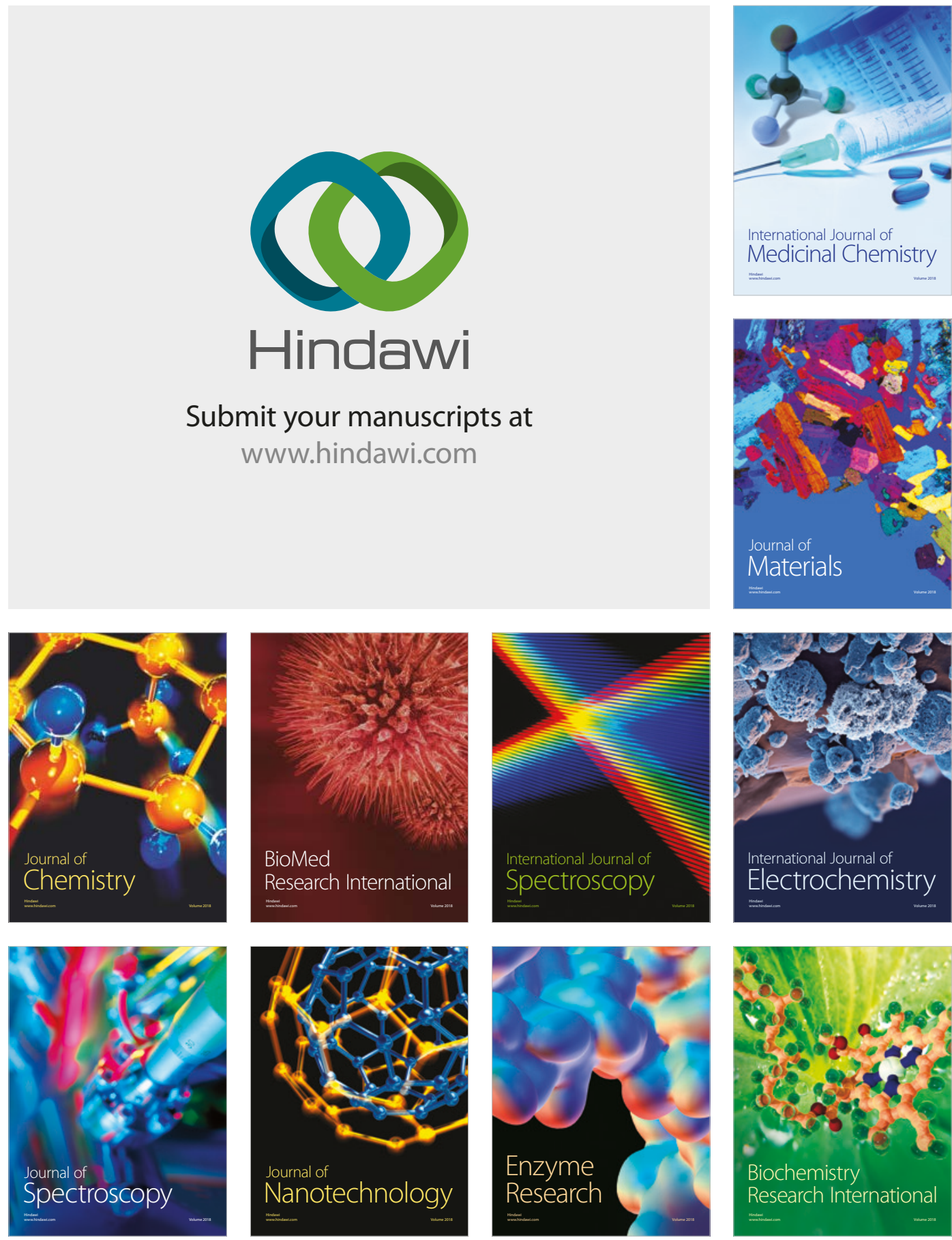
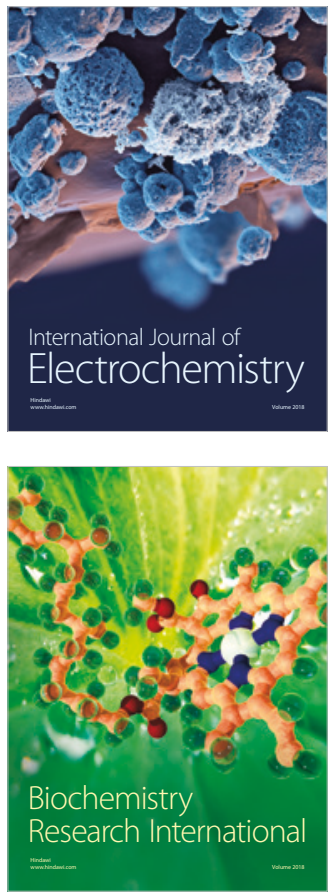